\title{
Temporal relationship between rainfall, temperature and occurrence of dengue cases in São Luís, Maranhão, Brazil
}

\author{
Relação temporal entre pluviosidade, temperatura \\ e ocorrência de casos de dengue em São Luís, Maranhão, Brasil
}

Fabrício Drummond Silva ${ }^{1}$

Alcione Miranda dos Santos ${ }^{1}$

Rita da Graça Carvalhal Frazão Corrêa ${ }^{2}$

Arlene de Jesus Mendes Caldas ${ }^{2}$

${ }^{1}$ Programa de PósGraduação em Saúde Coletiva, Universidade Federal do Maranhão (UFMA). Av. dos Portugueses 1966/ Pavilhão Pedagógico Paulo Freire/107, Cidade Universitária Bacanga. 65080-805 São Luís MA Brasil.

ajmc@elo.com.br ${ }^{2}$ Departamento de Enfermagem, UFMA. São Luís MA Brasil.

\begin{abstract}
This study analyzed the relationship between rainfall, temperature and occurrence of dengue cases. Ecological study performed with autochthonous dengue cases reported during 2003 to 2010 in São Luís, Maranhão. Data of rainfall and temperature were collected monthly. The monthly incidence of dengue cases was calculated by year $/ 100,000$ inhabitants. In order to identify the influence of climate variables and dengue cases different distributed lag models using negative binomial distribution were considered. Model selection was based on the lowest AIC (Akaike Information Criterion). Thirteen thousand, four hundred forty-four cases of dengue between 2003 and 2010 were reported, with peaks in 2005, 2007 and 2010. The correlation between rainfall and the occurrence of dengue cases showed increase in the first months after the rainy months. Occurrence of dengue cases was observed during all the period of study. Only rainfall-lag per three months showed a positive association with the number of cases dengue. Thus, this municipality is considered as an endemic and epidemic site. In addition, the relation between rainfall and dengue cases was significant with a lag of three months. These results should be useful to the future development of politics healthy for dengue prevention and control. Key words Dengue, Pluviometry, Temperature, Endemic disease, Epidemic
\end{abstract}

Resumo Este estudo analisou a relação entre a pluviosidade, temperatura e ocorrência de casos de dengue. Estudo ecológico, realizado no município de São Luís (MA), com os casos de dengue autóctone notificados no período de 2003 a 2010, e os dados mensais de pluviosidade e temperatura. A incidência mensal de casos de dengue foi calculada por ano/100.000hab. Para a identificação da influência das variáveis climáticas e casos de dengue foram ajustados diferentes modelos de defasagem distribuída, considerando a distribuição binomial negativa. A seleção dos modelos foi baseada no critério AIC (Akaike Information Criterion). Foram notificados 13.444 casos de dengue entre 2003 e 2010, com picos em 2005, 2007 e 2010. A correlação dos indices pluviométricos com a ocorrência da dengue mostrou aumento de casos nos primeiros meses subsequente aos chuvosos. Houve ocorrência de casos de dengue em todo o periodo estudado, caracterizando o município como endêmico-epidêmico. Além disso, a relação entre casos de dengue e quantidade de chuva foi significativa com defasagem de três meses. Estes resultados são úteis para o desenvolvimento futuro de políticas de saúde para controle e prevenção da dengue.

Palavras-chave Dengue, Pluviosidade, Temperatura, Doença Endemica, Epidemia 


\section{Introduction}

The climate and its variables such as rainfall and temperature have a great influence on society, especially concerning the main basic survival needs for mankind as air, water, food and shelter. Taking this on consideration, the human beings have been influencing inadvertently the local urban landscape through their activities, and in turn producing a chaotic urban space. Thus, this contributes to environmental degradation and the possible increase of diseases that encounter especially in urban places, favorable conditions for their spreading.

Climate changes may impact on human health by increasing incidence of infectious diseases, especially vector-borne diseases such as dengue. These infections are more often observed in tropical countries and considered one of the major public health problems due to global warming ${ }^{2}$.

Dengue is an acute febrile illness caused by flavivirus. Four different serotypes are known (DENV-1, DENV-2, DENV-3 and DENV-4). Clinically, dengue may have a benign or severe course. According to the way the disease manifests it may be sorted as dengue without warning signs, dengue with warning signs and severe. Currently, it is considered as the most important arboviral disease that affects human beings and a serious public health problem worldwide. Dengue is seen especially in tropical countries, where environmental conditions favor the development and proliferation of Aedes aegypti, the main vector ${ }^{3}$.

The Aedes aegypti mosquito uses natural or artificial containers with clean water (tires, cans, tanks, barrels, containers of water, potted aquatic plants, etc.) in order to lay its eggs. It has a domestic and peri-domestic habitat and lay its eggs in a short radius of oviposition sites (100 to 200m), favoring the development of immature forms and then presenting an ecological condition that makes this species predominantly urban ${ }^{4,5}$.

The larvae density of Aedes aegypti fluctuates according to seasonal climate variations, being higher in the seasons with higher rainfall indexes. The density depends on the number of potential available breeding-sites and that in turn makes susceptible the increase of dengue ${ }^{6}$. The vector metabolism rate increases in the warm months, and due to that, its life cycle is shortened in up to eight days? ${ }^{7}$.

The dengue-transmission patter is only through the bite of female mosquitoes, which after feeding on contaminated blood transmits the virus to a near susceptible host. When the mosquito feeds on a healthy man the cycle is closed, man - Aedes aegypti- man ${ }^{3}$.

In São Luís, the first cases of the classic dengue were detected in the neighborhood of Cohab - Anil in 1995. In 1996, the first dengue epidemic happened in the city with 4,641 notified cases ${ }^{5}$. Four thousand, two hundred ninety five (1997), 5,501(1998), 2,689(2005) and 3,432(2007) cases were also registered. In the last 10 years, 14,951 cases of dengue were notified ${ }^{8}$.

The climate effects throughout the area with high temperatures, abundant rains and significant humidity are favorable to the proliferation of diseases vectors such as dengue ${ }^{1}$. Dengue will continue to represent a major public health problem for many years, due to population growth and movement, uncontrolled urban sprawl, deficit in the water supply and the waste collection, breeding sites proliferation and the absence of an effective vaccine $e^{9,10}$. Thus, this study aimed to describe the relationship between rainfall, temperature and cases of dengue.

\section{Methods}

Ecological study performed with autochthonous dengue cases that were notified and confirmed from 2003 to 2010 in São Luís, Maranhão. Data of rainfall and temperature were collected monthly. São Luís is the capital of Maranhão situated in the northern part of this state. It is located on the shore and is featured by mangroves and beaches. Its average altitude is $32 \mathrm{~m}$ and geographical coordinates are $2^{\circ} 31^{\prime} \mathrm{LS}$ and $44^{\circ} 18^{\prime} \mathrm{LW}$.

The coastal vegetation is more often seen due to the tropical climate with a mean annual temperature around $26^{\circ}$ to $28^{\circ} \mathrm{C}$. The highest rainfall density extends from March to August with average rainfall of 2,000 to 2,200 mm. São Luis presents convective rains, that is, those that come from the displacement of air masses in the Equatorial Atlantic Ocean from February to March, and the Tropical Atlantic Ocean responsible for the drought from September to Novembro ${ }^{11}$. The population of the city was $1,011,943$ inhabitants in $2010^{12}$, with $828.19 \mathrm{~km}^{2}$ of extention ${ }^{11}$ and thus representing around $0.24 \%$ of the state territory.

The notified confirmed cases of dengue were obtained from the Superintendence of Sanitary and Epidemiological Surveillance (SVES) of the Municipal Health Bureau of São Luis and the data of rainfall and temperature (min- 
imum, mean and maximum) in the Climatology Laboratory of the Geoenvironmental Center at the State University of Maranhão (UEMA). The population estimates used to calculate the monthly and annual incidence of dengue cases were obtained from the Brazilian Institute of Geography and Estatistics ${ }^{12}$. The monthly incidence of dengue was calculated from the total cases of the month divided by the estimated population in the current year of study and multiplied by 100,000 . Thus, we obtained the incidence of the disease in every one hundred thousand inhabitants.

Different distributed lag models (DLM) were taken into consideration in order to identify the influence of climate variables on dengue cases ${ }^{13}$. The DLM assumes that the dependence of the variable $y_{t}$ in relationship with the explanatory variables $x_{t,}$ occurs over time rather than all at once, that is, the effect on $y_{t}$ in period $t$ is not explained only by the event $x_{t}$ in period $t$, but also by the temporal observation $x_{t}$ in periods $t-1, t-2$, etc. ${ }^{13}$.

The negative binomial distribution with mean $\mu_{t}$ was used for the dependent variables $y_{t}$, notified cases of dengue in month $t$, with $t$ being $1, \ldots, 96$. This model was used because the variance of the number of reported cases of dengue was higher than the average. This is featured as an over-dispersion of data. Thus, the MLD assumes $\mu_{t}$ being the average of the dependent variable $y_{t}$, $X_{i t-1}$ as the explanatory variables and their lags in the month and $\beta_{1}$ the parameters that measure the effects of lag $l(l=1,2, \ldots ., \mathrm{L})$. The term log $\left(N_{t}\right)$ known as offset, represents a covariate with linear coefficient equal to 1 .

$$
\log \left(\mu_{t}\right)=\log \left(N_{t}\right)+\sum_{l=1}^{L} \beta_{l} X_{i t-l}
$$

The variables were adjusted in separate models due to the existence of a linear relationship between the maximum, mean and minimum temperature variables (collinearity). Each variable was compared with the variable rainfall with lags of up to three months. The annual population data were entered in the regression models as an offset, using the logarithmic function.

The fittest model was chosen based on the criterion AIC (Akaike Information Criterion). The model with the lowest AIC is the best fit to the data. Data were analyzed using STATA 12.0 software. The level of significance was $5 \%$. The study was conducted using secondary public domain data from SINAN, respecting the anonymity of cases.

\section{Results}

Thirteen thousand, four hundred forty-four cases of dengue were registered in São Luís from 2003 to 2010 with peaks in 2005 (309.07/100,000 inhabitants), 2007 (358.43/100,000 inhabitants) and 2010 (276.39/100,000 inhabitants.). The highest incidences of dengue cases were observed in the months of May, June, July, August and September during the study period (Table 1).

When comparing the values of AIC, it is noticed that the lowest AIC were observed in the variables minimum temperature and rainfall with three months lag according to the adjusted model (Table 2).

It was observed that only the variable rainfall with three months lag was significantly associated with the number of dengue cases $(\mathrm{p}=0.026)$ (Table 3).

Regarding climate variables, the mean annual temperature showed low variation of $27.1^{\circ} \mathrm{C}$ in 2003 to $28.1^{\circ} \mathrm{C}$ in 2007 , decreasing to $27.3^{\circ} \mathrm{C}$ in 2010 (Figure 1). On the other hand, the highest rainfall index was recorded in 2009 (Figure 2).

\section{Discussion}

Taking into account the adopted model in this study, only rainfall index with three months lag showed a positive association with the number of dengue cases. Thus, we may confirm that the 10 $\mathrm{mm}$ increase in rainfall increases $1 \%$ the number of dengue cases up to three subsequent months.

In this study, we observed that the months of March and April of 2005 (7.903mm and $7.272 \mathrm{~mm}$ ) and 2007 (17.653 $\mathrm{mm}$ and $37.791 \mathrm{~mm})$ had higher rainfall indexes and from the following months there was an increase in dengue cases. These results are in accordance with those found in the literature, considering the time between the biological factor, transmission and registration of cases in the information system ${ }^{14,15}$.

The seasonal pattern of disease incidence coincides with the summer due to increased occurrence of rain and the higher temperature in this season $^{16-18}$. On the other hand, the rain seems to have a great influence in determining the period of occurrence of this disease $\mathrm{s}^{5}$.

In concordance with those statements, studies performed in the municipalities of São Sebastião - São Paulo and Rio de Janeiro - Rio de Janeiro, showed that rainfall did not only increase significantly the number of breeding sites available for development of the immature stages of the vec- 


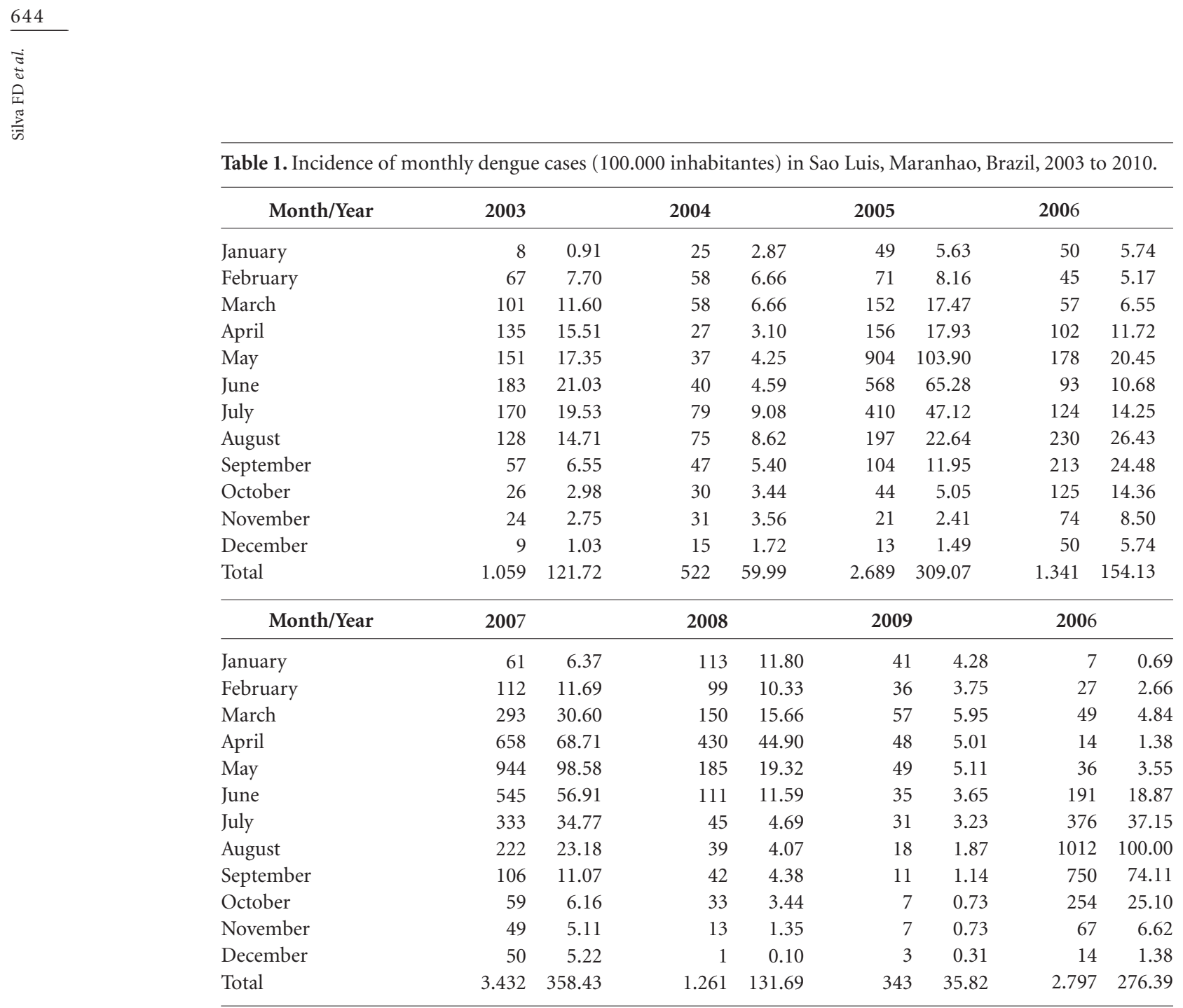

Source: SEMUS/SVES/SINAN

Table 2. Climate variables with different lags according to adjusted model. Sao Luis, Maranhao, Brazil, 2003 to 2010.

\begin{tabular}{llc}
\hline \multicolumn{1}{c}{ Variables } & \multicolumn{1}{c}{ Lag } & \multicolumn{1}{c}{ AIC $^{*}$} \\
\hline Mean temperature + rainfall & $\begin{array}{l}\text { one month } \\
\text { two months }\end{array}$ & $1,127.27$ \\
& $\begin{array}{l}1,118.27 \\
\text { three months }\end{array}$ & $1,099.84$ \\
Maximum temperature + & one month & $1,133.00$ \\
rainfall & two months & $1,123.47$ \\
& three months & $1,100.18$ \\
Minimum temperature + & one month & $1,123.24$ \\
rainfall & two months & $1,115.18$ \\
& three months & $1,095.59$ \\
& &
\end{tabular}

"AIC: Akaike Information Criterion

tor. It also generated more suitable environmental conditions for development of adults, as the temperatures were significantly higher in years when dengue epidemic started ${ }^{7,14}$.
Table 3. Estimates for the adjusted model with minimum temperature and rainfall variables. são Luis, Maranhao, Brazil, 2003 to 2010.

\begin{tabular}{llccc}
\hline \multicolumn{1}{c}{ Variables } & \multicolumn{1}{c}{ Lag } & PR & p & CI 95\% \\
\hline Minimum & one month & 0.90 & 0.357 & {$[0.73 ; 1.12]$} \\
temperature & two months & 0.92 & 0.441 & {$[0.75 ; 1.13]$} \\
& three months & 1.10 & 0.234 & {$[0.94 ; 1.29]$} \\
Rainfall & one month & 1.02 & 0.079 & {$[0.99 ; 1.04]$} \\
& two months & 1.00 & 0.705 & {$[0.99 ; 1.02]$} \\
& three months & 1.01 & 0.026 & {$[1.01 ; 1.02]$}
\end{tabular}

According to Araújo and Nunes ${ }^{1}$, the seasonal pattern of dengue incidence was concurrent with the summer because this season is rainier and with higher temperatures, occurring more frequently in urban centers where are places with more number of natural breeding sites. In São 


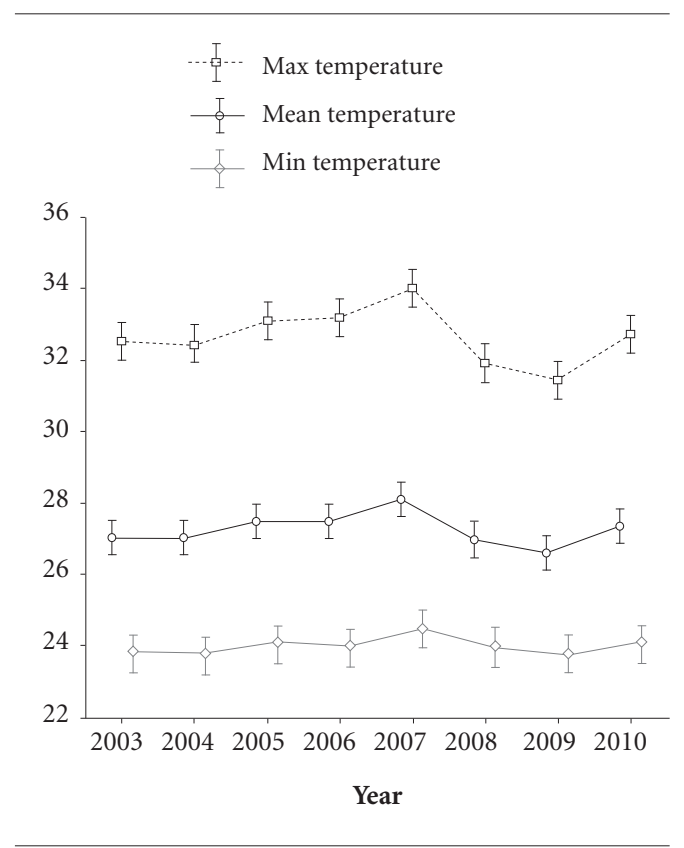

Figure 1. Mean, maximum and minimum temperaturas per year in Sao Luis, Maranhao, Brazil, 2003 to 2010 .

Source: SEMUS/SVES/SINAN

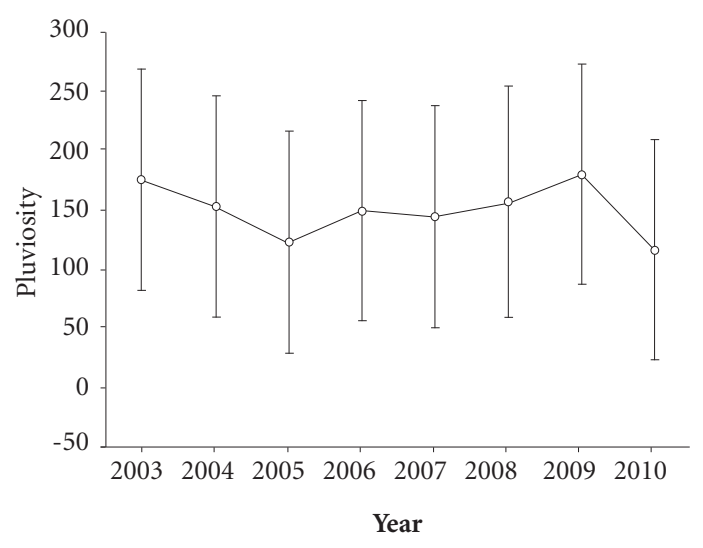

Figure 2. Indexes of rainfall per year in São Luis, maranhão, Brazi, from 3003 to 2010.

Source: SEMUS/SVES/SINAN

José do Rio Preto, a time series of dengue was analyzed in September 1990 and August 2002. They found years with higher and lower incidences, that is, epidemic years interspersed by interepidemic periods ${ }^{19,20}$, similar to our results.

Moore ${ }^{16}$ showed that temperature was not a good factor of larval abundance when studying the relationship between cases of dengue, temperature and rainfall, with the plenty of Aedes aegypti mosquitoes. Nevertheless, the amount and the number of days with rain may be a useful predictor of abundance. This is often accepted although it is necessary to consider that rates of viral infection in the vector also vary with climate conditions.

In a study about the distribution of Aedes aegypti mosquitos and dengue in the state of Maranhão, the municipalities of Imperatriz, Caxias, Balsas and São Luís (capital state), the rains were more often observed in the first semester (rainy season in the state), with peaks in March and April, with concentration of dengue cases in the period of higher rainfall ${ }^{21}$. These results are similar to the findings of this study in 2008. The contribution of other factors, such as increase of the amount of available breeding sites, larval abundance, density and rates of vector viral infection favor the increase in dengue cases ${ }^{14,16,22}$.

The infestation levels of Aedes albopictus, which oviposition occurs preferentially outside the household, seems to be more influenced by the rain. On the other hand, Aedes aegypti which is a totally domiciled vector uses many types of containers whose water is independent of rain, and thus, is less affected by the season ${ }^{23-25}$. This suggests that the transmission peaks $(2005,2007$ and 2010) found in São Luís, were not related to vector density, but with the increased survival of adult mosquitoes in the temperature and humidity of the rainy season.

Lack or inconsistency of information was one of the major difficulties faced by us in this study, mainly concerning to lack of diagnostic confirmation by laboratory exams that represents a significant number of cases that were not included. Despite these limitations, the results of this study allowed a diagnosis of the dengue cases situation in São Luís, showing the relationship with climate variables. Occurrence of dengue cases was observed in all the months and years studied, which allows us to feature the behavior of the disease in this city as endemic and epidemic. The rainfall index with three months lag, showed a positive association with the number of dengue cases. 


\section{Collaborations}

FDV da Silva conceived the project, carried out the data collection and drafted the manuscript, AM dos Santos was involved in the analysis, in- terpretation, and drafted the manuscript, RGCF Correa participated in the interpretation, drafted the article and AJM Caldas participated in the coordination and participated in all stages of the study and draft of the manuscript.

\section{References}

1. Araújo RR, Nunes JSA. Relações Geográficas entre o Clima e a incidência de dengue na cidade de São Luís MA. Rev Ciências Humanas 2005; 3(2):8-11.

2. Brasil. Ministério da Saúde. Mudanças climáticas e ambientais e seus efeitos na saúde: cenários e incertezas para o Brasil. Brasília: Organização Pan-Americana da Saúde; 2008.

3. Brasil. Ministério da Saúde (MS). Secretaria de Vigilância em Saúde. Guia de Vigilância Epidemiológica. Brasília: MS; 2006.

4. Medronho RA. Geoprocessamento e saúde: uma nova abordagem do espaço no processo saúde doença. Rio de Janeiro: Fundação Instituto Oswaldo Cruz; 1995.

5. Gonçalves Neto VS, Rebêlo JMM. Aspectos epidemiológicos do dengue no município de São Luís, Maranhão, Brasil, 1997-2002. Cad Saude Publica 2004; 20(5):1424-1431.

6. Souza SS, Silva IG, Silva HHG. Associação entre incidência de dengue, pluviosidade e densidade larvária de Aedes aegypti, no Estado de Goiás. Rev Soc Bras Med Trop 2010; 43(2):152-155.

7. Câmara FP, Gomes AF, Santos GT, Câmara DCP. Clima e epidemias de dengue no Estado do Rio de Janeiro. Rev Soc Bras Med Trop 2010; 42(2):137-140.

8. São Luís. Secretaria Municipal de Saúde. Relatório de Atividades. São Luís: Secretaria Municipal de Saúde/Superintendência de Vigilância Epidemiológica e Sanitária/Sistema de Informação de Agravos de Notificação; 2011.

9. World Health Organization (WHO). Dengue haemorrhagic fever: diagnosis, treatment, prevention and control. Geneva: WHO; 1997.

10. Holmes EC, Twiddy SS. The origin, emergence and evolutionary genetics of dengue virus. Infec Gen Evol 2003; 3(1):19-28.

11. Universidade Estadual do Maranhão (UEMA). Núcleo Geoambiental. Programa de Planejamento e Gestão Territorial. Ilha do Maranhão. São Luís: UEMA; 2011.

12. Instituto Brasileiro de Geografia e Estatística (IBGE). Censo demográfico. Rio de Janeiro: RJ; 2010.

13. Souza ICA, Vianna RPT, Moraes RM. Modelagem da incidência do dengue na Paraíba, Brasil, por modelos de defasagem distribuída. Cad Saude Publica 2007; 23(11):2623-2630.

14. Ribeiro AF, Marques GRAM, Voltolini JC, Condino MLF. Associação entre incidência de dengue e variáveis climáticas. Rev Saude Publica 2006; 40(4):671-676.
15. Gomes AF. Análise espacial e temporal da relação entre dengue e variáveis metereológicas na cidade do Rio de Janeiro no período de 2001 a 2009 [dissertação]. Rio de Janeiro: Escola Nacional de Saúde Pública Sérgio Arouca; 2011.

16. Moore CG. Predicting Aedes aegypti abundance from climatological data. In: Lounibos LP, Rey JR, Frank JH, editors. Ecology of mosquitoes. Vero Beach: Florida Medical Entomology Laboratory; 1985. p. 223-233.

17. Keating J. An investigation into the cyclical incidence of dengue fever. Soc Sci Med 2001; 53(12):1587-1597.

18. Teixeira MG, Costa MCN, Barreto ML, Barreto FR. Epidemiologia da dengue em Salvador - Bahia, 1995 1999. Rev Soc Bras Med Trop 2001; 34(3):269-274.

19. Mondini A, Chiaravalloti Neto F, Sanches MGY, Lopes JCC. Análise espacial da transmissão de dengue em cidade de porte médio do interior paulista. Rev Saude Publica 2005; 39(3):444-451.

20. Brasil. Ministério da Saúde (MS). Fundação Nacional de Saúde. Programa Nacional de Controle da Dengue. Brasília: MS; 2002.

21. Rebêlo JMM, Costa JML, Silva FS, Pereira YNO, Silva JM. Distribuição de Aedes aegypti e do dengue no Estado do Maranhão, Brasil. Cad Saude Publica 1999; 15(3):477-486.

22. Ferreira BJ, Souza MFM, Soares Filho AM, Carvalho AA. Evolução histórica dos programas de prevenção e controle da dengue no Brasil. Cien Saude Colet 2009; 14(3)961-972.

23. Pinheiro VCS. Frequency, diversity and productivity study on thee Aedes aegypti most preferred containers in the city of Manaus, Amazonas, Brazil. Rev Inst Med Trop 2002; 44(5):245-250

24. Donalísio MR, Glasser CM. Entomological surveillance and control of dengue fever vectors. Rev Bras Epidemiol 2002; 5(3):259-279.

25. Santos SL, Cabral ACSP, Augusto LGS. Conhecimento, atitude e prática sobre dengue, seu vetor e ações de controle em uma comunidade urbana do Nordeste. Cien Saude Colet 2011; 16(Supl. 1):1319-1330.

Artigo apresentado em 21/03/2015

Aprovado em 24/06/2015

Versão final apresentada em 26/06/2015 